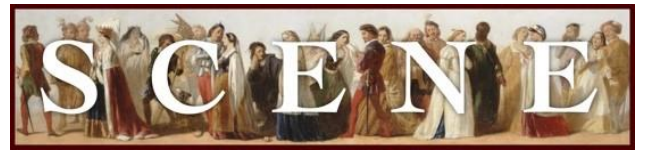

\title{
To Be or Not to Be ... a Puppet? Der Bestrafte Brudermord
}

by Madeline Lowry. Written on 2016-04-02. Published in 2017 Issue 1.

For the production: Der Bestrafte Brudermord (2016, The Hidden Room Theater Company, USA). See production details at the end of the review.

WHEN THINKING OF HAMLET, COMEDY IS NOT WHAT USUALLY COMES TO MIND, BUT PERHAPS IT should. After watching Hidden Room Theater's production of Der Bestrafte Brudermord, I can't imagine seeing Hamlet in any other way. Working with Tiffany Stern, Professor of Early Modern Drama at Oxford University, and the American Shakespeare Center, Hidden Room Theater workshopped Stern's theory about the mysterious manuscript from the 1700 s that was found buried deep in a monastery. Stern believed that this old German text was most likely meant to be performed as a puppet show. After seeing the Hidden Room Theater's production I couldn't agree more.

As part of the \#Shakespeare40o celebrations, the Folger Shakespeare Library sent a copy of Shakespeare's First Folio to each state. Texas A\&M University hosted the First Folio's stop in Texas. The Texas events included workshops, a film series, lectures, and more. Hidden Room Theater's Brudermord was part of these events.

The humor throughout this production was incredibly slapstick and absurd, which are not terms usually associated with Hamlet, but which worked perfectly. The puppets were flying in and out of scenes and stumbling their way throughout the play. There were moments when I was laughing so hard that I was crying; however, it never felt over the top. This is likely because the language of the play was very casual but still sounded "Elizabethan." You could tell that it was a Shakespearean play, but it was by no means hard to follow. The credit here goes to Christine Schmidle, who translated the play into English in a way that was humorous and effortless.

But the play was really made by the puppets themselves. Created by Mystery Bird Puppet Show and styled by Jennifer Rose Davis, the puppets really looked like Shakespearean characters. The outfits were decadent and it was easy to follow who was who. The attention to detail was incredible, and the Ghost of Hamlet's father looked like something out of a modern horror movie. It may seem impossible to capture or embody some of the major emotional elements of 
Shakespearean characters through puppets, but it was actually quite successful. It may have been the comedic aspect of the play that allowed them to do this, because the puppets were able to exaggerate every single action, but whatever it was, it worked. The puppets even addressed the audience directly every now and then, which enhanced the comedic atmosphere. It almost makes me wish that all Shakespearean plays were performed with puppets.

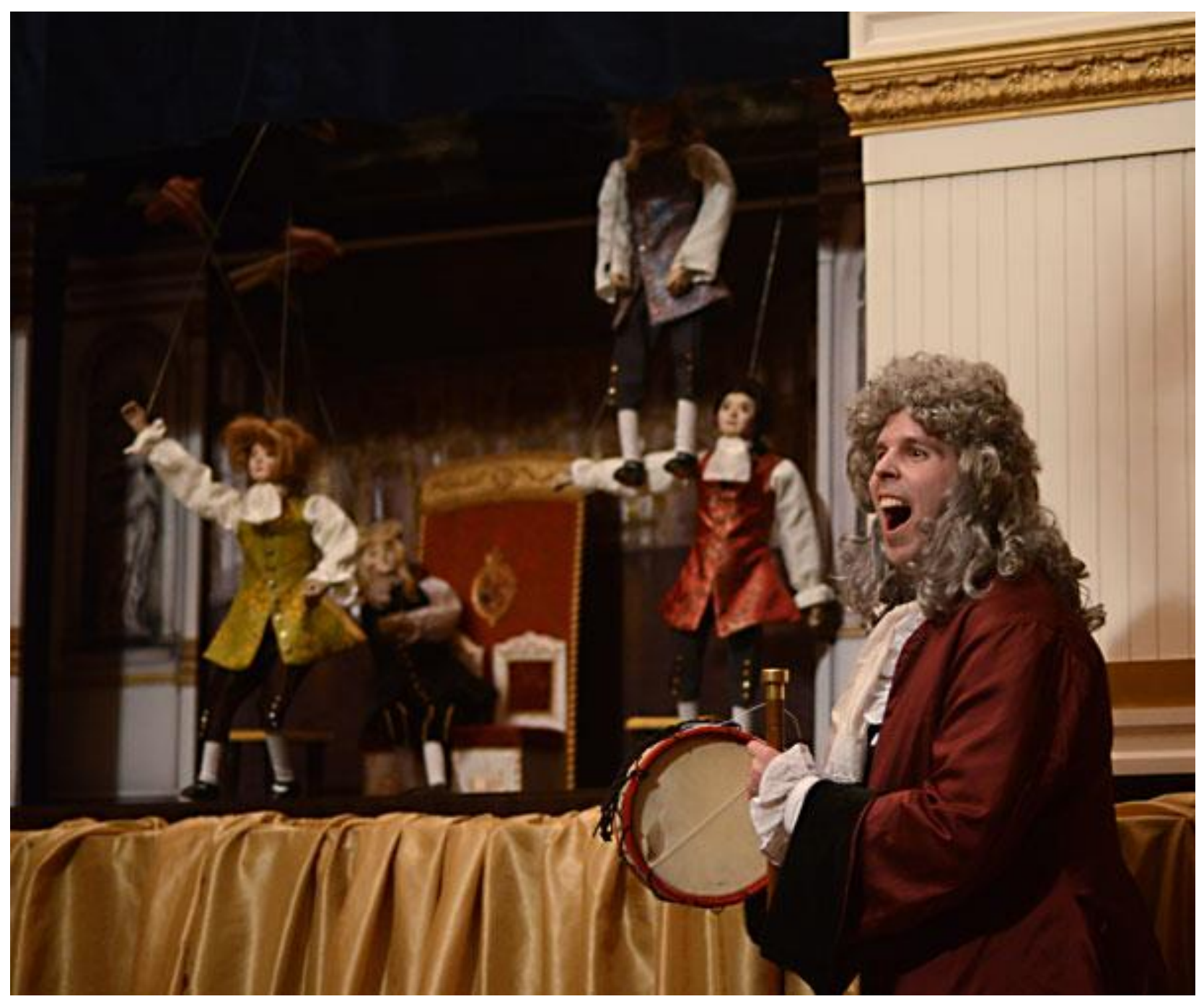

Figure 1: Narrator, Judd Farris, voicing several puppet roles in Der Bestrafte Brudermord (Photograph by Pat Jarrett)

However, we can't give all of the credit to the puppets. They were supported by Judd Farris and Jason Newman, who gave the puppets their voices. The two narrators stood in front and on the side of the puppet stage throughout the entire performance, giving voices to all of the characters. At the beginning of the show it felt a little awkward being able to actually see the narrators, but it was so easy to get completely engrossed in the show that the narrators began to blend with the puppets. The show was performed on two stages: an actual self-contained miniature stage for the puppets, complete with proscenium arch and curtain, as well as the 
playing space in front of the puppet-stage, where the narrators, fully dressed in Elizabethan clothes, danced, played instruments, and ventriloquized. At times, they even talked directly to the puppets, breaking into the contained narrative of the inset play. These interjections only added humor to the already hilarious production. But perhaps the narrators' greatest contributions came during the final battle scene between Hamlet and Laertes. The two narrators conducted their own fight in front of the stage while the puppets fought simultaneously behind them. This double presentation added to the intensity and reality of the violence, while still allowing the puppets' humor to play out.

The narrators played a significant role during the breaks between scenes. For the few minutes that the curtain was closed while the stage was being set, the narrators entertained the audience: whether delivering a song, interacting with specific audience members, or playing with random props, the narrators kept the cheerful atmosphere alive while the puppets were away. The props used during these breaks were also used during the show. The live performers used property noisemakers to imitate the sounds heard throughout the play, such as ocean waves and stomping. In this way, the narrators really became all the more important to enhancing the performance itself. They created the music and even got the audience involved by initiating booing and cheering.

While the props and music were great additions to the performance, the sets themselves really added to the believable Shakespearean effect. When I think of puppet shows, the sets tend to only be a minor aspect, but the attention to detail for this small stage puppet show really made this performance stand out. Jim Barnes, Davis, and Jim Strain did an amazing job at creating small details that went a long way. The scenes inside the castle were enhanced by the surrounding decorative columns and backdrops. These small details could easily be overlooked, but ultimately created the perfect Shakespearean environment for this comedy to unfold. The show itself was relatively short, unlike some productions of Shakespeare. At just over an hour long, this English translation of a German adaptation managed to add new original scenes and characters, such as a humorous portrayal of a peasant who had information about the battle that was about to take place between Hamlet and Laertes. Although this production shortened the original Shakespeare narrative, it allowed the text to be more exciting and refreshing for modern audiences. The new characters and scenes created something fresh for the audience members that were familiar with Hamlet, and brought the play back to life. These new scenes somehow managed to bring in new elements, but still remained true to the intentions of the original Hamlet quite successfully.

Overall, Hidden Room Theater managed to do the impossible-make Hamlet brisk, hilarious, and new. Despite the old foreign title, they managed to make this performance dynamic and 
stimulating for present-day audiences. I think it is safe to say that Stern was very likely right with her theory that this old German text was actually meant to be performed as a puppet show. But whether she was right or not, I'm certainly glad that Hidden Room Theater experimented with it because puppets and Shakespeare really do work incredibly well together.

Madeline Lowry is a 4th year English and Anthropology double major at Texas A\&M University, where she enjoys studying nineteenth-century literature, transnational studies, and material culture. In 2016 she was an intern for the World Shakespeare Bibliography.

\section{Production Details}

\section{General}

Title

Year

Theater Company

Theaters

Start Date

End Date
Der Bestrafte Brudermord 2016 The Hidden Room Theater Company The Amity Building (USA)

2016-04-01

2016-04-01

\section{Creatives}

Director
Puppeteer
Puppeteer
Set Design And Construction
Puppet Theatre Construction
Puppet Theatre Construction
Costumes and Props
Music, Styling, and Costume
Puppet Styling
Set Design And Construction
Puppet Theatre Construction
NARrator
Puppeteer
Puppeteer
Puppet Theatre Construction
Puppeteer
Narrator
Puppeteer

BETH BURNS

KIM ADAMS

CAMI ALYS

JIM BARNES

JIM BARNES

JAY BAUN

JENNIFER Rose Davis

JENNIFER DAVIS

JENNIFER Rose DAVIS

JENNIFER Rose DAvis

IA ENSTERA

JUDD FARRIS

JOSEPH GARLOCK

RYAN HAMILTON

SCOTT JONES

JEFF MILLS

JASON NEWMAN

LAURENCE PEARs 
Puppet Design and Construction Mystery Bird Puppet Show

TRANSLATOR

CHRISTINE SCHMIDLE

RESEARCH DIRECTOR

TIFFANY STERN

Set Design AND Construction

JIM STRAIN 